\title{
Coaching and evidence-based learning
}

\author{
Peter Shipley*
}

\begin{abstract}
Although the Ontario Provincial Police has existed since 1909, the Ontario Provincial Police Academy has only existed in various forms since the first 'School of Instruction' was created in 1920. For the first 11 years of the organizations existence, training was not formally delivered. In fact it was very informal and a basic trial and error process by shadowing an already serving, experienced officer. Clearly, over the last century, there have been a significant change in how training is designed and delivered. The Canadian Association of Chiefs of Police Research Foundation, Canadian Association of Police Educators, and the Canadian Society for Evidence Based Policing, among others, are all committed to pursuing a more evidence based approach to training.

In attempting to address the future training needs of police officers, the curriculum needs to be designed with a constructivist principled approach. According to a number of researchers, the essential features of constructivism in practice include the following:
\end{abstract}

"Learning is characterized by cognitively active learners; learning should happen in context and be structured around related themes or primary concepts; new knowledge constructs are built upon prior knowledge; new knowledge should be applied and feedback provided; learner self-reflection on the learning process is a key learning activity" (Yoders, 2014, p.12).

This process is exactly what needs to occur in police training and education, especially in the training and education of not just new recruits, but Coach Officers, as well. New recruits have to learn basic information that is fundamental to policing such as the Constitution, the Canadian Charter of Rights and Freedoms, and Provincial Statutes, for example, before they can ever 'enforce the law'. We clearly shouldn't be teaching a recruit to handcuff and search someone before they have a clear understanding of what a citizen's rights and freedoms are, as well as what is an indictable or nonindictable offence or what is meant by summary offences. Learning has to be constructed on these related themes and built upon. Subsequent to that, they must understand and apply the correct 'arrest procedure' which incorporates key elements including informing the person that they are under arrest, as well as providing them with their rights to counsel and ensuring that they understand those rights.

As noted in Yoders' book, Vygotsky's (1978) work in the 'zone of proximal development' (ZPD) is absolutely critical in police training, especially for Coach Officers (Yoders, 2014). Schunk (2012) describes this area as the difference between what a learner can do with or without assistance. Vygotsky's early work of overcoming this difference is "how all knowledge is constructed and where cognitive development occurs" (as cited in Yoders, 2014, p.13). In police training, once recruits master the theoretical knowledge required to be a police officer, they have the opportunity to apply this knowledge in practical, realistic simulations. Related to this training is a key element called scaffolding. This process is the educational technique that helps the learner close the gap in cognitive ability found in the ZPD (Yonders, 2014). A well trained, knowledgeable, experienced Coach Officer will be able to effectively guide new recruits through the ZPD.

Another important concept for Coach Officers to understand is what Collins (1991) describes as 'cognitive apprenticeship'. This is where the transmission of expert knowledge to a novice occurs in a gradual manner via specific processes which include:

a) task or problem modelling or demonstration;

b) provision for performance feedback;

c) scaffolding via decreasing levels of assistance as the learner progresses, allowing the learner to become increasingly autonomous; and

d) mentoring by monitoring progress, evaluating performance, and helping overcome specific weaknesses (Collins, Brown \& Holum, 1991).

Although this 'cognitive apprenticeship' is exactly what should occur in policing, we can always improve how this is constructed both formally and informally in the field with Coach Officers. The focus of how this 'cognitive apprenticeship' will work in the OPP will be tested significantly when a large number of experienced officers retire and take all of their knowledge with them. Below is an example of how it applies and the appropriate steps as noted by (a, b, c, d).

After the recruits have successfully completed their basic training they are assigned a Coach Officer or Field Training Officer (as they are called in the United States). The recruit is on probation for one year (varies with agency) after they have completed all their basic training requirements. The Coach Officer is responsible for teaching, mentoring, supervising, and assessing their performance. The Coach Officer is also responsible to ensure that a new recruit can transition from the theoretical safe haven of the Academy to real-world application. 
The Coach Officer, for instance, will demonstrate how to conduct a professional vehicle stop, then have the recruit perform that task (a). If they make a mistake on the steps, they are provided feedback (b) and are provided opportunity to demonstrate proficiency again. One of the ways our police training has implemented scaffolding is through a process of feedback and achievement. For instance, recruits will ride with a Coach Officer until the recruit has demonstrated proficiency to the Coach that they have developed the competencies to ride alone. This process enables recruits to have their 'day wings', which means they can ride on their own, with a Coach nearby, because they have demonstrated proficiency in such areas as the safe operation of the police vehicle, knowledge and accurate application of the law, and professional use of discretion. Once the recruit has demonstrated proficiency of being on their own during the day, they receive their 'night wings'; then they become totally autonomous and can be recommended for full-time employment (c).

There have been recruits who have been released during their probationary period because they just cannot make that transition from the theoretical aspects to practical application in the field. Just because a recruit scores $95 \%$ on their Academy examinations, that does not guarantee they will make a good police officer. One of the key questions is whether or not they are able to 'apply' what they have learned. Recruits will make mistakes, which is one of the ways in which we all learn. When a learner understands how to apply knowledge in different contexts, then transfer has occurred" (Ertmer, \& Newby, 2013, p.52). If, however, the recruit is not demonstrating some of the competencies, then they are put on a 'work improvement plan' (WIP) and provided with opportunities to succeed. They are mentored continually by Coaches who monitor their progress, evaluate performance, and assist them to overcome specific weaknesses (d).

Although behavioural and cognitive strategies are very valuable and applicable to police training, the constructivist strategies appear to have a higher correlation to the levels of learner's task knowledge. 'As all students' learning will involve errors, tasks should offer opportunities for selfassessment, correction, peer discussion, teacher feedback, and other 'reality checks'"' (Teachers Toolbox, n.d., para 1). In fact Smith (2000) notes that "almost every training program I design benefits from a combination of behaviourist and constructivist approaches" (also cited in Cronje 2006, p. 405). A blend of all three approaches maybe needed or, as Ertmer and Newby (2013) point out, we need 'adaptive leaners' when "optimal conditions do not exist, when situations are unpredictable and task demands change, when the problems are messy and ill-formed, and the solutions depend on inventiveness, improvisation, discussion and social negotiation" (p. 63). In other words, these authors describe very succinctly, that 'police learners' must be 'adaptive learners'. If we are going to develop and support adaptive police learners, then organizations need to develop 'predictive learning analytics' that are specific to the individual as well as to the organization. Although a fairly new phenomenon from higher education, there is a direct application for police leaders to improve how training and education is approached.

Brown, Iszler and Hall (2012) indicate that between $60-80 \%$ of learning takes place outside of formal contexts, yet we spend the bulk of our staff development resources on formal training. Van Dam (2012) estimates that the rate is even higher, at a $90 \%$. Still others report evidence of up to $70 \%$ of what is needed to learn to perform the tasks of the job do, in fact, occur informally in the field or "on-the-job" (Giovengo, 2017, Biech, 2017, Kirkpatrick \& Kirkpatrick, 2015). It is safe to conclude that the majority of our learning occurs informally. The high quality training that recruits receive, make us hopeful that the 'errors' in judgment that new recruits make in the field will be minor in nature. The role of the Coach Officer has never been more critical than it is today. Police training institutions must take an evidenced-based approach to learning in order to design and implement the best possible training curriculum that focuses on supporting the Coach Officer in the field.

This latest research just confirms Collins' (1991) work on the importance of 'cognitive apprenticeship'. If most of the learning is occurring informally, 'in the field' and not at the formal police training institution, then policing needs to pursue more evidence-based approaches, as well as developing the appropriate 'predictive learning analytics' in order to have the right kind of supports available to our Coach Officers in the field.

\section{CONFLICT OF INTEREST DISCLOSURES}

The author declares that there are no conflicts of interest.

\section{AUTHOR AFFILIATIONS}

*Provincial Police Academy, Orillia, ON.

\section{REFERENCES}

Biech, E. (2017). The art and science of training. Alexandria, VA: Association for Talent Development.

Brown, R.M., Iszler, B.P.L., \& Hall, A. (2012). Corrections learning and performance: a vision for the 21st century [NIC White Paper]. Washington, DC: US Department of Justice, National Institute of Corrections. Retrieved from https://info.nicic.gov/nicrp/system/files/026506.pdf

Collins, A. (1991). Cognitive apprenticeship and instructional technology. In L. Idol and B. Fly Jones (Eds.) Educational values and cognitive instruction: Implications for reform (pp121-138). Hillsdale, NJ: Lawrence Erlbaum Associates.

Collins, A., Brown, J. S., \& Holum, A. (1991). Cognitive apprenticeship: Making thinking visible. American Educator, 15(3), 6-11, 38-46. Retrieved from http://citeseerx.ist.psu.edu/viewdoc/download? doi=10.1.1.124.8616 \&rep=repl\&type $=$ pdf

Cronjé, J. (2006). Paradigms regained: Toward integrating objectivism and constructivism in instructional design and the learning sciences. Educational Technology Research and Development, 54(4), 387-416.

Ertmer, P. A., \& Newby, T. J. (2013). Behaviorism, cognitivism, constructivism: Comparing critical features from an instructional design perspective. Performance Improvement Quarterly, 26(2), 43-71.

Giovengo, R. (2017). Training law enforcement officers. Boca Raton, FL: CRC Press

Kirkpatrick, J. \& Kayser-Kirkpatrick, W. (2015). An introduction to the New World Kirkpatrick Model. Newnan, GA: Kirkpatrick Partners. Retrieved from http://www.kirkpatrickpartners.com/Portals/O/Resources/ White\%2OPapers/Introduction\%2Oto\%2Othe\%2OKirkpatrick\%2ONew\%20 World\%20Model.pdf

Schunk, D. (2012). Learning theories: An educational perspective (6th ed.). Boston, MA: Pearson Education, Inc.

Smith, D. S. (2000). Re: Paper \#48. Message posted to ITForum mailing list, 5 Dec. ITForum is a list service offered by the Association for Educational Communications \& Technology (AECT). Bloomington, IN: subscription available from: http://listserv.lt.unt.edu/mailman/listinfo/itforum 
Teachers Toolbox (n.d.). Constructivist teaching strategies. Retrieved from http:// www.teacherstoolbox.co.uk/Constructivist_Teaching_Strategies.htm

Van Dam, N. (2012). Designing learning for a 21 st century workforce. Training and Development, 49-53.
Vygotsky, L. S., Cole, M., John-Steiner, V., Scribner, S., \& Souberman, E. (1978). Mind in Society: The Development of Higher Psychological Processes. Cambridge, MA: Harvard University Press

Yoders, S. (2014). Constructivism theory and use from 21 st century perspective. Journal of Applied Learning Technology, 4(3), 12-20. 